\title{
ANALISIS PENERAPAN GOOD GOVERNANCE TERHADAP KINERJA ORGANISASI MELALUI KEPERCAYAAN KONSUMEN
}

\author{
Oleh : \\ Sri Fadilah \\ (Dosen Program Studi Akuntansi Universitas Islam Bandung)
}

\begin{abstract}
In Indonesia today, the development of non-governmental organizations such as Lembaga Amil Zakat that manages funds of Zakat, Sadaqah infak and thus flourished as civil society. In reality, there is a gap between the potential for a large charity (20 trillion) with the realization of a very small charity (1 trillion). Phenomenon indicates the low performance of Zakat Management Organisation (OPZ), particularly the Institute Amil Zakat (LAZ). These demands pose a challenge to LAZ to do good governance. Furthermore, we will have an impact on the high demands of society for accountability and transparency of $L A Z$. Then it becomes a challenge for $L A Z$ to make efforts in order to improve performance in particular OPZ, especially LAZ. The results of this study are expected to be a reference for the development of models of good governance and LAZ performance assessment in Indonesia. With the purposes of this study the variables studied were good governance, consumer trust and organizational performance. The purpose of the study wanted to see the effect of the application of good governance on organizational performance through consumer trust. The research method used is an explanation, and data analysis tools used were SEM with PLS approach.
\end{abstract}

Keywords: Good Governance, Consumer Trust and Organizational Performance.

\section{Latar Belakang}

Beberapa tahun terakhir ini di Indonesia, isu yang berkaitan dengan konsep pelaksanaan zakat baik sebagai kewajiban agama secara pribadi maupun zakat sebagai komponen keuangan publik sangat populer. UU No. 38 tahun 1999 tentang Pengelolaan Zakat menjadi payung hukum yang lebih kuat dalam pengelolaan zakat di Indonesia, sebagai upaya untuk mendukung fakta bahwa Indonesia adalah negara yang penduduk muslimya terbesar di dunia, yaitu berjumlah $80 \%$ dari sekitar 220 juta penduduk Indonesia adalah sebesar 180 juta penduduk muslim (Eri Sudewo:2008) yang memiliki kewajiban menunaikan zakat baik zakat fitrah dan zakat harta. Kondisi tersebut semestinya menjadi potensi zakat yang luar biasa berkaitan dengan upaya penghimpunan zakat. Di bawah ini disajikan potensi zakat yang dapat dihimpun, yaitu:

Tabel 1

Potensi Zakat di Indonesia

\begin{tabular}{|l|l|l|l|}
\hline \multicolumn{1}{|c|}{ Keterangan } & Potensi Zakat & \multicolumn{1}{|c|}{ Keterangan } & Potensi Zakat \\
\hline PIRAC (Kompas .2008) & Rp 9,09 trilyun & $\begin{array}{l}\text { Direktur Thoha Putra } \\
\text { Center } \\
\text { Semarang, (2009) }\end{array}$ & Rp 100 triliun \\
\hline $\begin{array}{l}\text { UIN Syarif } \\
\text { Hidayatullah(2004) }\end{array}$ & Rp 19,3 trilyun & $\begin{array}{l}\text { Baznas } \\
\text { (Republika:2005) }\end{array}$ & Rp 19,3 triliun \\
\hline $\begin{array}{l}\text { Adiwarman \&. Azhar Syarief } \\
\text { 2009) }\end{array}$ & Rp 20 triliun & $\begin{array}{l}\text { FoZ Forum } \\
\text { Zakat:2009) }\end{array}$ & Rp 20 triliun \\
\hline
\end{tabular}


Dengan banyak berdirinya lembaga amil zakat yang sekarang berjumlah 400 LAZ (FoZ.2011), dapat dijadikan sebagai alternatif bagi masyarakat dalam menyalurkan dana zakatnya selain kepada Badan Amil Zakat yang berjumlah 50.956 (Baznas.2009). Selain itu Lembaga Amil Zakat ini pada akhirnya dapat diharapkan sebagai media untuk menjembatani dalam pencapaian potensi zakat di Indonesia. diperkirakan masih terdapat sekitar 600 OPZ baik LAZDA maupun UPZ yang telah berdiri baik yang berbasis masjid maupun perusahaan yang tidak atau belum terdaftar pada FoZ (Forum Zakat). Namun demikian, berkembangnya lembaga pengelola zakat (BAZ/LAZ), sampai saat ini belum disertai dengan minat masyarakat untuk membayar zakat pada lembaga zakat tersebut. Dampaknya adalah belum optimalnya pengelolaan zakat di Indonesia. Hal tersebut sangat disayangkan karena betapa besarnya potensi zakat di Indonesia, jika tidak dikelola dengan baik. Tabel 1.2 menyajikan data yang berkaitan dengan realisasi penghimpunan zakat:

Tabel 2

Realisasi Penghimpunan Zakat

\begin{tabular}{|c|l|l|}
\hline No & \multicolumn{1}{|c|}{ Keterangan } & \multicolumn{1}{c|}{ Jumlah } \\
\hline 1 & Data dari Depag (2007) & BAZ: Rp 12 miliar dan LAZ: Rp 600 miliar \\
\hline 2 & Data Depag (2008) & BAZ dan LAZ: Rp 900 miliar \\
\hline 3 & Forum Zakat (FoZ) (2009) & LAZ dalam data FoZ: Rp 900 miliar \\
\hline 4 & IZDR (2004-2008) & Rp 61,3 miliar menjadi Rp 361 milyar \\
\hline
\end{tabular}

Berdasarkan dari fenomena tersebut, hal lain yang yang harus dicermati adalah kenyataannya dengan adanya UU pengelolaan zakat, dan banyak berdirinya lembaga amil zakat ternyata belum berdampak pada kesadaran masyarakat untuk menyalurkan zakatnya pada lembaga pengelola zakat (BAZ/LAZ) pada yang semakin meningkat terhadap pentingnya berzakat. Berdasarkan hasil riset PIRAC terdapat 29 juta keluarga sejahtera yang menjadi warga sadar zakat. Di sisi lain saat ini, diperkirakan hanya ada sekitar 12 13 juta muzaki yang membayar zakat lewat LAZ, berarti masih ada lebih dari separuh potensi zakat yang belum tergarap oleh LAZ. Gambaran tersebut harus dipandang sebagai tantangan bagi lembaga pengelola zakat khususnya LAZ untuk memperbaiki kinerjanya khususnya berkaitan dengan penghimpunan dana zakat. Tantangan tersebut harus disikapi sebagai upaya perbaikan bagi LAZ untuk lebih profesional dalam melakukan kegiatannya.Tujuan khusus riset ini adalah ingin melihat pengeloaan zakat, dengan segala ketentuannya dan dampaknya pada kinerja LAZ. Karena jika dana zakat pada LAZ dikelola dengan baik semestinya mampu mengangkat harkat dan martabat kaum yang tertinggal, namun kenyataannya potensi tersebut hanya angan-angan belaka. Padahal Indonesia sebagai sebuah negara, yang memiliki potensi yang sangat besar dan strategis dalam pengumpulan zakat, di mana Indonesia penduduknya sebagian besar muslim. Jelaslah bahwa zakat seyogyanya dapat dijadikan sebagai sumber pendapatan bagi pemerintah untuk mengentaskan kemiskinan. Berkaitan dengan kemiskinan, di bawah ini tersaji data tentang penduduk miskin Indonesia baik dalam jumlah maupun presentase sebagai berikut:

Tabel 3

Jumlah dan Persentase Penduduk Miskin di Indonesia

\begin{tabular}{|c|c|c|}
\hline Tahun & $\begin{array}{c}\text { Jumlah Penduduk Miskin } \\
\text { (Juta) }\end{array}$ & Persentase Penduduk Miskin \\
\hline 2006 & 39,30 & $17,75 \%$ \\
\hline 2007 & 37,17 & $16,58 \%$ \\
\hline 2008 & 41,70 & $21,92 \%$ \\
\hline
\end{tabular}

Sumber: Diolah dari data Survei Sosial Ekonomi Nasional 
Kemudian, meskipun keberadaan organisasi pengelola zakat yang semakin banyak di Indonesia, namun jika umat Islam selama ini membayar atau menunaikan zakat tidak secara lembaga seperti membayar zakat dengan menyerahkan kepada sanak keluarga terdekat, maka upaya mencapai potensi zakat masih akan tidak tercapai. Sistem pembayaran zakat tersebut bukan berarti jelek atau tidak baik namun dampak sosialnya sempit dan bersifat jangka pendek. Akan berbeda dengan pembayaran zakat secara lembaga dan sistematis, seperti membayar zakat kepada lembaga zakat baik BAZ dan LAZ akan berdampak luas karena dana zakat akan dikelola dalam bentuk programprogram sosial yang terarah dan terstruktur dan dampak sosialnya bersifat jangka panjang. Adapun urgensi penelitian ini, dengan melihat berbagai masalah yang disinyalir menjadi penghalang mengapa potensi zakat di Indonesia yang sangat besar tersebut belum terkelola dengan baik dan optimal sehingga berdampak pada kinerja Oragnisasi Pengelola Zakat (OPZ) khususnya LAZ masih rendah. Adapun masalah tersebut dari berbagai sumber disajikan sebagai berikut: (â) Badan pengelola zakat dianggap tidak profesional karena belum menerapkan prinsip akuntabilitas dan transparansi (Almisar Hamid.2009:10); (b) Sistem birokrasi dan good governance masih lemah berkaitan dengan pengelolaan zakat di Indonesia sehingga berdampak pada rendahnya akuntabilitas dan transparansi LAZ (Asep Saefuddin Jahar:2006:7).

Selain penyebab permasalahan belum optimalnya pengelolaan zakat akan berdampak pada belum cukup baiknya kinerja yang dicapai OPZ khusus LAZ, Permasalahan lain yang perlu untuk diperbaiki berdasarkan (survey CID dompet Dhuafa dan LKIHI-FHUI:2008:11-16) telah terrangkum ke dalam tujuh permasalahan utama, yaitu: (1) Permasalahan Kelembagaan, (2) Permasalahan Peraturan Perundang-undangan, (3) Pengumpulan, pendistribusian dan pendayagunaan zakat, (4) Pengawasan dan Pelaporan, (5) Korelasi Zakat dengan Pajak, (6) Peran Serta Masyarakat dan (7) Sanksi dan Sengketa Zakat

Dari uraian permasalahan yang selama ini yang disinyalir sebagai kendala dalam pengelolaan zakat di Indonesia, menunjukkan kendala yang sangat kompleks. Hal tersebut berawal dari ketidakpercayaan masyarakat terhadap lembaga pengelola zakat (LAZ) tersebut (CID Dompet Dhuafa dan LKIHI-FHUI:2008:19-20). Untuk mendukung hal tersebut, harus diciptakan pengelolaan perusahaan yang baik dan optimal hingga dapat mencapai kinerja yang baik.

Selanjutnya hasil riset Feroz, Sanjay and Raymod (2008:128) menyatakan bahwa terdapat pengaruh secara timbal balik antara corporate governance dengan kinerja organisasi. Di mana implementasi corporate governance secara efektif akan menciptakan kinerja organisasi yang tinggi, sebaliknya dengan tercapainya kinerja organisasi yang tinggi menunjukkan akuntabilitas organisasi yang tinggi. Bahkan hasil riset Aras dan Crowther (2008:444), terhadap 100 perusahaan di pasar modal di Turki (FTSE), menyebutkan bahwa terdapat pengaruh antara good governance dengan sustainability (keberlanjutan perusahaan di masa datang). Sustainability diartikan sebagai bentuk kinerja strategis perusahaan karena bersifat jangka panjang.

Penerapan good governance merupakan mekanisme pengendalian untuk mengatur dan mengelola operasi dengan tujuan untuk meningkatkan kemakmuran dan akuntabilitas perusahaan, dengan tujuan akhirnya untuk mewujudkan shareholders value. Pendapat ini didukung oleh Newel dan Wilson (2002) dalam aitikelnya yang berjudul "A Premium for Good Governance" yang dikutip oleh Marjana (2002), bahwa secara teoritis praktik good governance dapat meningkatkan nilai perusahaan, di antaranya kinerja organisasi, mengurangi risiko akibat tindakan pengelola yang cenderung menguntungkan diri sendiri dan dapat meningkatkan kepercayaan investor atau stakeholders (mustahik dan muzaki). Hal senada dikemukakan oleh Khotibul, Karina dan Sekar Ayu (2009:1), 
bahwa implementasi prinsip good corporate governance dilakukan oleh bank syariah sebagai upaya untuk meningkatkan kepercayaan konsumen. Alasan riset tersebut bahwa sebagai lembaga keuangan bank merupakan institusi yang sarat dengan pengaturan sehingga perbankan merupakan the most heavy regulated industry in the world. Keberadaan bank, merupakan keniscayaan mengingat bank merupakan lembaga yang eksistensinya sangat membutuhkan kepercayaan masyarakat (fiduciary relation). Unsur kepercayaan masyarakat terhadap perbankan merupakan suatu hal yang sangat esensial, sehingga bank perlu menjaga kepercayaan konsumen untuk mencegah adanya rush atau penarikan dana masyarakat secara besar-besaran.

Hal tersebut sangat relevan dengan unit analisis penelitian yaitu LAZ yang memiliki karakteristik sama dengan bank syariah baik secara organisasi, operasional maupun regulasi. Artinya LAZ sebagai lembaga intermediasi yang mengelola zakat, kepercayaan konsumen (mustahik dan muzaki) menjadi hal yang sangat penting. Untuk meningkatkan kepercayaan konsumen tersebut, implementasi prinsip good governance menjadi hal yang diperlukan. Apalagi inti masalah penelitian ini adalah rendahnya kepercayaan konsumen yang berdampak pada tidak tercapainya target penghimpunan zakat.

Lebih lanjut, dengan terciptanya kepercayaan konsumen pada LAZ, diharapkan terjadi peningkatan konsumen baik secara kuantitatif maupun kualitatif, sehingga target penghimpunan zakat tercapai. Dengan tercapainya target tersebut sebagai bukti bahwa tujuan dan kinerja organisasi terpenuhi. Hal tersebut sesuai dengan hasil riset Buytendijk, F. (2008:2) dalam artikel Performance Leadership, menyatakan bahwa, terdapat keterkaitan antara kepercayaan konsumen dengan kinerja perusahaan. Selanjutnyam dijelaskan bahwa dengan dengan kepercayaan yang tinggi dari konsumen organisasi akan mendapatkan respon dan persepsi positif sehingga organisasi mampu menciptakan berbagai kinerja yang tinggi.

\section{Rumusan Masalah}

Berdasarkan urgensi penelitian di atas maka penelitian ini akan melihat dan menganalisis bagaimana pengaruh penerapan good governance terhadap kinerja organisasi melalui kepercayaan konsumen pada LAZ seluruh Indonesia.

\section{Kerangka Pemikiran}

Banyak pengertian yang telah disampaikan oleh para ahli dan peneliti, diantaranya, pengertian corporate governance, OECD dalam Siswanto dan Aldridge (2005:2) mendefinisikan corporate governance sebagai beikut: corporate governance is the system by which business corporation are directed an controlled. The corporate governance structure specifies the distribution of rights and responsibilities among different participants in corporation, such as the board, the managers, shareholders and other stakeholders and spells out of the rules and procedures and for making decision on coporate affairs. By doing this, it also provides the structure through which the company objectives are set, and the means of attaining those objectives and monitoring performance.

Maksud definisi tersebut bahwa suatu sistem yang dipergunakan untuk mengarahkan dan mengendalikan kegiatan bisnis perusahaan. Corporate governance mengatur pembagian tugas, hak dan kewajiban mereka yang berkepentingan terhadap kehidupan perusahaan, termasuk para pemegang saham, dewan pengurus, para manajer dan semua anggota stakeholders non pemegang saham. Tujuan dari good corporate governance seperti yang dinyatakan dalam OECD (1999: 34) adalah bertujuan, (1) untuk mengurangi kesenjangan antara pihak-pihak yang memiliki kepentingan dalam suatu 
perusahaan, (2) meningkatkan kepercayaan bagi para investor dalam melakukan investasi, (3) mengurangi biaya modal, (4) menyakinkan kepada semua pihak atas komitmen legal dalam pengelolaan perusahaan dan (5) penciptaan nilai bagi perusahaan termasuk hubungan antara para stakholders. Selanjutnya dalam rangka menerapkan good governance perlu adanya standar atau prinsip yang dijadikan pedoman dalam praktik pengelolaan perusahaan untuk meningkatkan nilai dan kelangsungan perusahaan. Organization for Economic Cooperation and Development (OECD,1999:25) telah mengembangkan prinsip-prinsip sebagai berikut: (a) Fairness, (b) Transparancy, (c) Accountability, dan (d) Responsibility.

Unit analisis penelitian ini adalah LAZ seluruh Indonesia terdiri dari LAZNAS maupun LAZDA, adalah organisasi sektor publik yang kegiatan utamanya adalah melakukan peran intermediasi pengelolaan dana ZIS, maka prinsip-prinsip good governance yang digunakan dalam penelitian ini mendasarkan pada keputusan Menteri Negara BUMN No. 117/M-MBU/2002, bahwa dalam penerapan good corporate governance di BUMN dikenal lima prinsip utama. Kelima prinsip tersebut adalah (a) responsibility, (b) accountability, (c) fairness, (d) tranparancy dan (e) independency. Uraian dari masing-masing prinsip tersebut sebagai berikut: (1) Pertanggungjawaban (Resposibility) adalah kesesuaian di dalam pengelolaan perusahaan terhadap peraturan perundang-undangan yang berlaku dan prinsip-prinsip korporasi/organisasi yang sehat; (2) Akuntabilitas (Accountability) adalah kejelasan fungsi, pelaksanaan dan pertanggungjawaban rapat umum pemegang saham, komisaris atau dewan pengawas dan direksi serta pemilik modal sehngga pengelolaan perusahaan terlaksana secara efektif dan efisien; (3) Keadilan (Fairness) adalah perlakuan yang adil dan setara di dalam memenuhi hak-hak stakeholders yang timbul berdasarkan perjanjian dan peraturan perundang-undangan yang berlaku untuk menjamin bahwa perusahaan dikelola secara prudent untuk kepentingan stakeholder secara fair dan menghindarkan terjadinya praktik korporasi yang merugikan; (4) Transparansi (tranparancy) adalah keterbukaan dalam melaksanakan proses pengambilan keputusan dan dalam mengemukakan informasi materiil dan relevan mengenai perusahaan. Transparansi berhubungan dengan kualitas informasi yang disampaikan perusahaan; (5) Kemandirian (Independency) adalah keadaan di mana perusahaan dikelola secara profesional tanpa bantuan kepentingan dan tekanan dari pihak yang tidak sesuai dengan peraturan perundang-undangan yang berlaku dan prinsip-prinsip korporasi atau organisasi yang sehat.

Banyak terdapat pengertian atau definisi tentang kepercayaan konsumen (consumer trust). Kreitner dan Kinicki (2001:422) mengemukakan bahwa kepercayaan konsumen merupakan keyakinan satu pihak mengenai maksud dan perilaku pihak yang lainnya. Kepercayaan konsumen didefinisikan sebagai penyedia produk atau jasa dapat dipercaya atau diandalkan dalam memenuhi janjinya (Sideshmuhk. et al. 2002:17). Definisi serupa dikemukakan oleh Peppers and Rogers (2004:71), adalah kualitas yang mencerminkan baiknya hubungan seseorang dengan pihak lain. Konsumen memiliki kepercayaan pada organisasi melalui aktivitas organisasi tersebut. Kepercayaan konsumen merupakan salah satu cara yang paling cepat untuk membangun hubungan kerelasian organisasi dalam jangka panjang. Hanya melalui kepercayaan konsumen terhadap kerelasian, informasi dapat dikembalikan pada organisasi. Kepercayaan berperan dalam meningkatkan kemampuan konsumen untuk menentukan pilihan, kerelasian yang didasarkan pada kepercayaan. Banyak hubungan profesional terjalin berdasarkan konsep kepercayaan terhadap agen. Khususnya, organisasi jasa, harus banyak mempelajari tentang keinginan atau kebutuhan konsumen sebelum mereka membuat rekomendasi secara profesional untuk menarik minat konsumen. 
Pemasaran yang efektif tergantung pada pengembangan dan pengelolaan kepercayaan konsumen sehingga konsumen secara khusus akan membeli atau menggunakan suatu jasa sebelum mengalaminya (Shamdasani dan Balakrishan.2000:403). Pengelolaan kepercayaan konsumen ditentukan dengan cara mengoptimalkan sumber daya pemberi jasa, teknologi dan sistem yang digunakan dalam rangka menciptakan kepercayaan konsumen. Kreitner dan Kinicki (2001:422) menyatakan, kepercayaan konsumen merupakan keyakinan suatu pihak mengenai maksud dan perilaku pihak lainnya. Secara konseptual, (Morgan dan Hunt. 1994:23), menyebutkan bahwa kepercayaan konsumen akan tercipta jika suatu pihak memiliki keyakinan terhadap integritas dan reliabilitas pihak lain. Selanjutnya menurut Rambat dan Hamdani (2008:175), bahwa keyakinan konsumen pada suatu pihak yang berkaitan dengan penyediaan barang jasa tercermin dari keputusan konsumen untuk membeli produk/menggunakan jasa dari organisasi yang dipercayai tersebut. Artinya terdapat keterkaitan antara kepercayaan konsumen dengan keyakinan konsumen untuk mengambil keputusan membeli produk/menggunakan jasa. Hal tersebut tercermin pada bertambahnya jumlah konsumen dari waktu ke waktu, bahkan secara sukarela konsumen akan melakukan kegiatan persuasif bagi konsumen lain untuk melakukan seperti apa yang dia lakukan (mouth to mouth communication).

Literatur tentang kepercayaan menyarankan, bahwa keyakinan pada pihak yang mendapat kepercayaan adalah reliabel dan integritas tinggi, disertai dengan kualitas yang konsisten, kompeten, jujur, bertanggungjawab dan baik. Kepercayaan konsumen tidak hadir begitu saja, tetapi dari proses yang lama sampai kedua belah pihak saling mempercayai. Dalam proses terbentuknya kepercayaan konsumen dipengaruhi oleh faktor-faktor seperti, reputasi organisasi, besar atau kecilnya organisasi, saling menyenangi antara konsumen dengan organisasi maupun antara konsumen dengan karyawan organisasi. Kepercayaan konsumen diyakini berperan dalam pembentukan persepsi konsumen bagi organisasi jasa (Donney and Canon. 1997:38).

Kemudian berkaitan dengan kualitas jasa, maka apabila konsumen merasa telah memperoleh kualitas jasa yang sesuai dengan harapannya maka konsumen akan melakukan pembelian dan penggunaan jasa kembali sebagai bentuk dari loyalitas konsumen, juga secara suka rela menyampaikan informasi dari mulut ke mulut kepada konsumen lain. (Rambat dan Hamdani .2008:175), dan pada akhirnya akan meningkatkan profitabilitas organisasi (Kotler.2004:125). Hal tersebut tercermin dari banyaknya konsumen yang kembali. Selanjutnya Shamdasani dan Balakrishan (2000:421) menggunakan integritas dan reliabilitas sebagai indikator untuk mengukur kepercayaan konsumen dan menemukan bahwa contact personel dan physical environment mempengaruhi kepercayaan konsumen. Selanjutnya kepuasan pelanggan mempengaruhi kepercayaan konsumen yang berdampak pada komitmen konsumen.

Selanjutnya, konsumen harus bisa merasakan bahwa konsumen dapat mengandalkan organisasi. Namun membangun kepercayaan konsumen membutuhkan waktu yang lama dan akan berkembang setelah pertemuan yang berulang kali dengan konsumen. Yang lebih penting, kepercayaan konsumen berkembang setelah seorang individu mengambil risiko dan berhubungan dengan partnernya (melakukan pembelian produk atau jasa kembali secara berulang). Hal ini menunjukkan bahwa membangun hubungan yang dapat dipercaya akan lebih mungkin terjadi dalam sektor industri tertentu, terutama yang melibatkan pengambilan risiko oleh konsumen dalam jangka pendek atau jangka panjang. Kepuasan konsumen terhadap nilai pelayanan dan organisasi menuntun meraka untuk komit dan loyal kepada organisasi tersebut. Konsumen hanya akan loyal kepada organisasi ketika didahului oleh rasa percaya (Blomerat and Gaby.2001:153). Ketika kepercayaan konsumen kepada produk atau jasa telah terbentuk konsistensi 
kualitas produk dan jasa, maka akan berdampak kepada komitmen dan loyalitas. Menurut Rambat dan Hamdani (2008:175), kepercayaan adalah hal penting bagi konsumen, karena kebanyakan konsumen akan mengutamakan untuk tetap menjadi konsumen suatu organisasi, ketika mereka telah percaya kepada organisasi tersebut.

Kepercayaan konsumen bagi LAZ, didefinisikan sebagai tingkat keyakinan muzaki dan mustahik bahwa LAZ telah mengambil langkah paling tepat, yang akan menguntungkan dan membantu muzaki dan mustahik dalam mencapai tujuan. Yaitu bagi muzaki merasa percaya dan tenang kala muzaki menyerahkan dana zakatnya untuk dikelola oleh LAZ. Bagi mustahik merasa percaya dan diperlakukan sebagaimana mestinya sebagai penerima dana ZIS dengan berbagai program pendistribusian dana ZIS. Rasa percaya konsumen bagi LAZ berdampak pada pengambilan keputusan konsumen untuk menitipkan dana ZIS yang dipercayai dan bagi mustahik untuk menerima dana ZIS. Selanjutnya, kepercayaan konsumen pada LAZ tercermin dari peningkatan jumlah konsumen dari tahun ke tahun yang akan menimbulkan peningkatan pada penghimpunan dana ZIS. Selain itu, kepercayaan konsumen akan berdampak pada tingkat kembali konsumen untuk menggunakan jasa LAZ.

Ide balanced scorecard pertama kali dipublikasikan dalam artikel Robert S Kaplan dan David P Norton di Harvard Business Review tahun 1992 dalam artikel berjudul "Balanced Scorecard-Measures that Drive Performance". Menurut Kaplan dan Cooper (1998:87) mendefinisikan Balanced Scorecard sebagai berikut: a measurement and management system that views a business unit's performance from four perpectives: financial, customer, internal business process, and learning and growth. Berdasarkan kutipan tersebut, dapat disimpulkan bahwa balanced scorcard merupakan suatu sistem manajemen, pengukuran dan pengendalian yang secara cepat, tepat dan komprehensif dapat memberikan pemahaman kepada manajer tentang kinerja bisnis. Dalam pengukuran kinerja akan memandang unit bisnis dari empat perspektif yaitu perspektif keuangan, perspektif pelanggan, perspektif proses bisnis internal dalam perusahaan serta proses pembelajaran dan pertumbuhan.

Balanced Scorecard merupakan konsep manajemen kinerja kontemporer yang mulai banyak diaplikasikan pada organisasi publik, termasuk organisasi pemerintahan juga diterapkan pada Organisasi Pengelola Zakat (OPZ) seperti LAZ dan BAZ. Balanced Scorecard dinilai tepat untuk organisasi publik, karena balanced scorecard tidak hanya menekankan pada aspek kuantitatif dan finansial, tetapi juga aspek kualitatif dan nonfinansial. Hal tersebut sejalan dengan organisasi sektor publik yang menempatkan laba bukan sebagai ukuran kinerja utama, namun pelayanan yang cenderung bersifat kualitatif dan nonfinansial. Meskipun konsep balanced scorecard lahir di dunia bisnis, organisasi publik juga dapat mengadopsi konsep balanced scorecard dengan beberapa modifikasi. Pengadopsian balanced scorecard ke dalam organisasi publik bertujuan untuk meningkatkan kinerja organisasi publik, karena kasus di beberapa organisasi besar yang menerapkan balanced scorecard menunjukkan bahwa balanced scorecard merupakan alat manajemen yang komprehensif dan powerful untuk mendongkrak kinerja organisasi.

Meskipun pada awalnya didesain untuk organisasi bisnis yang bergerak di sektor swasta, namun pada perkembangannya balanced scorecard dapat diterapkan pada organisasi sektor publik dan organisasi nonprofit lainnya. Perbedaan utama organisasi publik dengan organisasi bisnis terutama adalah pada tujuannya (profit maximization) sedangkan sektor publik bersifat nonprofit (service maximization). Organisasi bisnis berfokus pada ukuran-ukuran kuantitatif dan finansial, misalnya laba bersih, laba per lembar saham, return on investment, dan sebagainya. Ukuran kinerja finansial tersebut sebenarnya tepat digunakan ketika organisasi berada pada era industri, namun ketika organisasi menghadapi era revolusi teknologi informasi dan komunikasi serta era 
ekonomi berbasis pengetahuan (knowledge based economy). Jika hanya mengandalkan ukuran kinerja finansial akan menyebabkan organisasi ketinggalan dan kehilangan arah. Hal ini disebabkan ukuran finansial tidak cukup untuk menuntun dan mengevaluasi perjalanan organisasi melalui lingkungan yang kompetitif dan merupakan ukuran kinerja masa lalu yang didasarkan pada data akuntansi historis.

Kaplan dan Norton (1996:102) memberikan petunjuk bahwa balanced scorecard memberikan para eksekutif kerangka kerja yang komprehensif untuk menterjemahkan visi dan strategi organisasi ke dalam seperangkat ukuran kinerja yang terpadu. Balanced scorecard menterjemahkan misi dan strategi ke dalam berbagai tujuan dan ukuran yang tersusun ke dalam dalam empat perspektif, yaitu: financial, customers \& stakeholders, internal business process, serta employees and organization capacity. Kerangka balanced scorecard tersebut tidak terbatas untuk organisasi bisnis, akan tetapi organisasi publik dapat menggunakannya dengan penempatan tumpuan yang berbeda, Jika dalam organisasi bisnis tumpuannya adalah perspektif finansial, maka dalam organisasi publik tumpuannya adalah perspektif customers \& stakeholders, karena pelayanan publik merupakan bottom line organisasi. Selanjutnya, fokus utama dalam organisasi publik adalah misi organisasi yaitu melayani dan meningkatkan kesejahteraan masyarakat. Dari misi tersebut diformulasikan strategi-strategi yang akan dilakukan untuk pencapaian misi tersebut. Gambar berikut menguraikan keterkaitan strategi organisasi tersebut kemudian diterjemahkan ke dalam empat perspektif, yaitu perspektif customers and stakeholders, perspektif financial, perspektif internal business process, dan perspektif employees \& organization capacity.

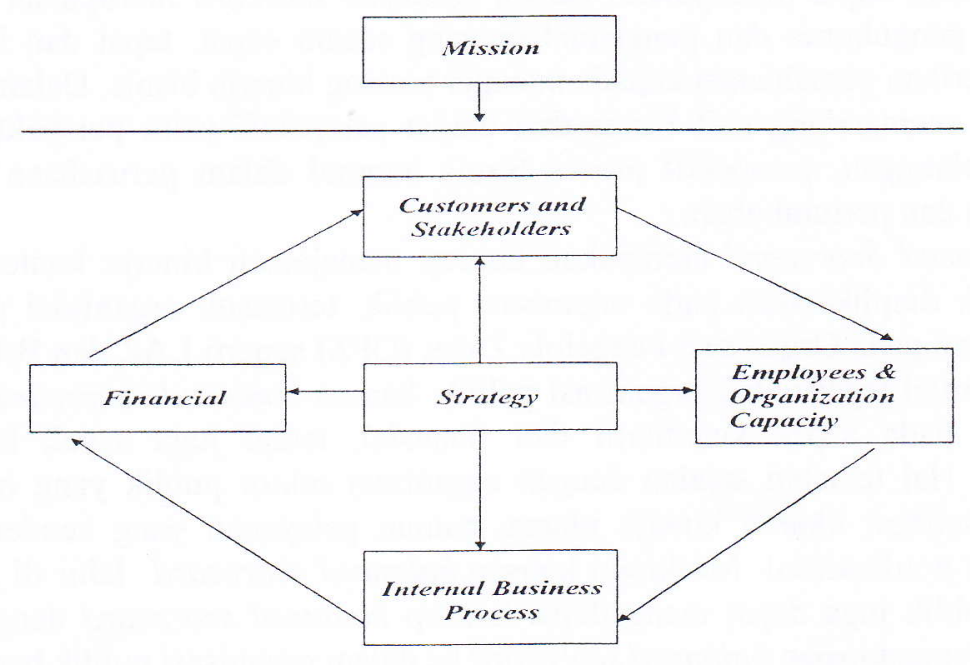

Sumber: Rohm. Howard (2004)

\section{Gambar 1}

\section{Balanced Scorecard Pada Organisasi Publik}

Adapun penjelasan masing-masing perspektif dari Gambar 1 sebagai berikut:

\section{a. Perspektif customers and stakeholders}

Tinjauan dari perspektif customers and stakeholders pada organisasi sektor publik pada dasarnya ingin mengetahui bagaimana customers and stakeholders melihat organisasi. Customers and stakeholders pada sektor publik yang utama adalah masyarakat pembayar zakat dan masyarakat pengguna layanan publik, untuk organisasi pengelola zakat adalah muzaki sebagai pihak yang menyerahkan zakat dan mustahik sebagai pihak 
yang menerima dana ZIS. Oleh karena itu, perspektif customers and stakeholders organisasi LAZ berfokus untuk memenuhi kepuasan masyarakat khususnya umat Islam. Kepuasan customers and stakeholders tersebut akan memicu perspektif customers and stakeholders dapat digunakan ukuran sebagai berikut: (1) Citizen satisfaction; (2) Service coverage; dan (3) quality and standards.

b. Perspektif financial

Perspektif keuangan dalam organisasi publik adalah untuk menjawab bagaimana organisasi meningkatkan pendapatan dan mengurangi biaya pengelola dan bagaimana kita melihat pembayar zakat?. Perspektif keuangan menjelaskan apa yang diharapkan oleh penyedia sumber dana finansial yang utama yaitu para muzaki (khusus untuk LAZ). Dengan demikian LAZ harus berfokus pada sesuatu yang diharapkan muzaki, yaitu mengharapkan zakat yang telah dikeluarkannya itu digunakan secara ekonomi, efisien, dan efektif, serta memenuhi harapan prinsip transparan dan akuntabilitas publik. Meskipun organisasi seperti LAZ tidak mengejar laba, namun LAZ perlu berupaya bagaimana meningkatkan pendapatan yang berasal dari dana ZIS dan tingkat efektifitas pelayanan yang diberikan oleh LAZ. Dengan demikian pada perspektif keuangan dapat digunakan ukuran berikut: (1) Upaya untuk meningkatkan dana ZIS yang dihimpun dan diberdayakan; (2) Effectivity of services; (3) Peningkatan jumlah dana ZIS yang dihimpun; dan (4) Peningkatan jumlah dana ZIS yang diberdayakan.

\section{c. Perspektif internal business process}

Pada perspektif proses bisnis internal berupaya untuk membangun keunggulan organisasi melalui perbaikan proses bisnis internal organisasi secara berkelanjutan. Tujuan strategik dalam perspektif proses bisnis internal adalah mendukung perspektif customers and stakeholders dan perspektif financial. Dalam perspektif proses bisnis internal organisasi mengidentifikasikan proses kunci yang harus dikelola dengan baik agar terbangun keuangan organisasi yang baik. Pertanyaan yang harus dijawab oleh organisasi adalah: "(1) kita harus unggul di bidang apa?; dan (2) bagaimana kita membangun keunggulan?". Pencapaian tujuan strategik pada perspektif ini akan berdampak pada kepuasan customers and stakeholders. Beberapa tujuan atau sasaran strategik pada proses bisnis internal misalnya peningkatan proses pelayanan, perbaikan siklus layanan, peningkatan kapasitas infrastruktur, pemutakhiran teknologi dan pengintegrasian proses layanan customers and stakeholders secara langsung akan mempengaruhi kepuasan customers and stakeholders dan secara tidak langsung akan berdampak pada kinerja keuangan. Dalam rangka meningkatkan kinerja pada perspektif internal business process organisasi sektor publik harus mengidentifikasi dan mengukur kompetensi inti organisasi, mengidentifikasi proses utama pelayanan, mengidentifikasi teknologi utama yang perlu dimiliki dan menentukan ukuran kinerja dan target kinerja. Pada LAZ keunggulan organisasi dapat didesain dari inovasi produk yang dapat memuaskan muzaki dan memberdayakan mustahik, serta pengembangan jaringan sistem informasi yang dapat memudahkan muzaki untuk menyalurkan zakatnya dan memudahkan mustahik menerima zakat. Dengan demikian pada perspektif proses bisnis internal dapat digunakan ukuran sebagai berikut: (1) Inovation of product dan (2) Management Information System.

\section{d. Perspektif employees and organization capacity}

Perspektif internal business process dan perspektif customers and stakeholders dalam balanced scorecard, mengidentifikasi parameter-parameter untuk membangun keunggulan organisasi. Target dan ukuran kesuksesan akan terus berubah seiring dengan perubahan waktu. Oleh karena itu, organisasi harus mampu berinovasi, berkreasi dan belajar. Organisasi perlu melakukan perbaikan secara terus menerus dan menciptakan pertumbuhan secara berkelanjutan. Dalam organisasi sektor publik seperti LAZ, 
perspektif employees and organization capacity difokuskan untuk menjawab pertanyaan ; "bagaimana organisasi terus melakukan perbaikan dan menambah nilai bagi customers and stakeholders?". Sasaran dan tujuan strategik yang ditetapkan pada perspektif employees and organization capacity akan berpengaruh terhadap perspektif lain, yaitu perspektif internal business process dan perspektif customers and stakeholders. Beberapa sasaran strategik pada perspektif employees and organization capacity tersebut antara lain: (1) peningkatan keahlian pegawai; (2) peningkatan komitmen pegawai; (3) peningkatan kemampuan membangun jaringan; dan (4) peningkatan motivasi pegawai. Ukuran kinerja untuk perspektif employees and organization capacity untuk LAZ difokuskan kepada "amilin" sebagai subjek pengelola zakat. Dengan demikian ukuran kinerja pada perspektif employees and organization capacity dapat digunakan ukuran: (1) Skill coverage; (2) Personel income dan welfare; dan (3) Personel satisfaction.

Berdasarkan kerangka teoritis yang telah diuraikan sebelumnya serta dukungan penelitian terdahulu, maka dapat ditarik hipotesis: "Terdapat pengaruh penerapan good governance terhadap kinerja organisasi melalui kepercayaan konsumen pada Lembaga Amil Zakat (LAZ) seluruh Indonesia"

\section{Metode Penelitian}

Metode penelitian yang direncanakan dalam penelitian ini adalah penelitian yang bersifat penjelasan (explanatory research), karena merupakan penelitian yang menjelaskan hubungan kausal di antara variabel-variabel (Cooper dan Schindler, 2006:154). Selanjutnya, untuk memperoleh data yang dibutuhkan untuk membuktikan hipotesis penelitian, menggunakan beberapa teknik pengumpulan data, yaitu Kuesioner, Wawancara dan Dokumentasi.

Dalam penelitian ini, untuk variabel good governance dan kinerja organisasi menggunakan instrumen penelitian kuesioner dengan skala interval, sehingga perlu dilakukan pengujian validitas dan reliabilitas instrumen, sedangkan untuk variabel kepercayaan konsumen menggunakan data internal Lembaga Amil Zakat (LAZ). Adapun pengujian terhadap instrumen penelitian akan dijelaskan sebagai berikut:

\section{Pengujian validitas instrumen (test of validity)}

Uji validitas dilakukan untuk mengetahui apakah alat ukur yang telah disusun benar-benar mengukur apa yang perlu diukur. Karena skala pengukuran dari data adalah interval maka uji validitas dalam penelitian ini menggunakan korelasi product moment. Berdasarkan hasil pengolahan menggunakan korelasi Pearson product moment $(r)$ :

\section{Tabel 4}

Hasil Uji Validitas Kuesioner

\begin{tabular}{|l|c|c|l|}
\hline \multicolumn{1}{|c|}{ Variabel } & Kisaran nilai $\mathbf{r}$ & Rkritis & Keterangan \\
\hline Good Governance & $0,431-0,869$ & 0,30 & Semua valid \\
\hline Kinerja Organisasi & $0,431-0,869$ & 0,30 & Semua valid \\
\hline
\end{tabular}

Sumber: Hasil pengolahan data

Pada Tabel 3.1 dapat dilihat nilai indeks validitas setiap butir pernyataan lebih besar dari 0,30 , hasil ini mengindikasikan bahwa semua butir pertanyaan yang diajukan valid dan layak digunakan untuk analisis selanjutnya.

\section{Pengujian reliabilitas instrumen (test of reliability)}

Reliabilitas dapat diartikan sebagai suatu karakteristik terkait dengan keakuratan, ketelitian dan kekonsistenan, dengan koefisien korelasi Sperman-Brown. 
Tabel 5

Hasil Uji Reliabilitas Kuesioner Penelitian

\begin{tabular}{|l|c|c|c|}
\hline \multicolumn{1}{|c|}{ Kuesioner } & $\begin{array}{c}\text { Jumlah } \\
\text { Pertanyaan }\end{array}$ & Koefisien Reliabilitas & Keterangan \\
\hline Good Governance & 20 & 0,953 & Reliabel \\
\hline Kinerja Organisasi & 20 & 0,953 & Reliabel \\
\hline
\end{tabular}

Sumber: Hasil pengolahan data

Hasil uji reliabilitas menunjukkan bahwa kuesioner keduat variabel yang diteliti sudah andal sehingga dapat dilanjutkan pada analisis berikutnya.

Target populasi dalam penelitian ini adalah Lembaga Amil Zakat yang terdaftar di Forum Zakat sebagai anggota aktif yang terdiri dari LAZNAS dan LAZDA yang terdaftar pada FoZ sebagai anggota aktif. Teknik penentuan sampel adalah Proportional Stratified Random Sample. Adapun penentuan sampel menggunakan rumus Slovin, dengan tingkat kekeliruan (d) sebesar 0,05:

Tabel 6

Banyaknya Unit Sampel dari Setiap Strata LAZ

\begin{tabular}{|c|c|c|}
\hline Lembaga Amil Zakat (LAZ) & N & N \\
\hline LAZ Nasional (LAZNAS) & 18 & 16 \\
\hline LAZ Daerah (LAZDA) & 32 & 28 \\
\hline Total & $\mathbf{5 0}$ & $\mathbf{4 4}$ \\
\hline
\end{tabular}

Sumber: Hasil penghitungan sampel

Dari jumlah target populasi yang berjumlah $50 \mathrm{LAZ}$, yang mengisi kuesioner dalam penelitian ini berjumlah $41 \mathrm{LAZ}$, terdiri dari 14 LAZNAS dan 27 LAZDA, sedangkan $9 \mathrm{LAZ}$ tidak bersedia dijadikan sebagai target populasi/responden penelitian.

Sesuai dengan perumusan masalah, tujuan penelitian, perumusan hipotesis dan jumlah data yang akan dikumpulkan maka metode analisis data yang digunakan dalam penelitian ini adalah menggunakan partial least square (PLS). Partial least squares (PLS) dikembangkan sebagai alternatif pemodelan dengan persamaan struktural yang dasar teorinya lemah. Pada penelitian ini partial least square digunakan untuk mengetahui besarnya pengaruh penerapan good governance terhadap kinerja organisasi melalui kepercayaan konsumen pada LAZ seluruh Indonesia.

\section{Hasil Penelitian dan Pembahasan}

Pengaruh penerapan good governance terhadap kinerja organisasi melalui kepercayaan konsumen, dianalisis menggunakan structural equation modeling, metode alternatif dengan partial least square. Sama halnya dengan SEM berbasis covariance, pada SEM berbasis variance juga terbentuk 2 model, yaitu model pengukuran dan model struktural. Melalui model pengukuran dengan indikator refleksif akan dinilai validitas dari masing-masing indikator dan menguji reliabilitas dari konstruk indikator yang dinilai. Indikator yang memiliki loading factor kurang dari 0,50 akan didrop dari model, sedangkan composite reliability yang dianggap memuasakan adalah lebih besar dari 0,70 . Berikut ini disajikan model pengukuran dari masing-masing variabel (construct) yang digunakan dalam penelitian ini.

Variabel penerapan good governance diukur menggunakan lima indikator, bobot faktor (loading factor) masing-masing indikator dalam membentuk variabel penerapan good governance dapat dilihat pada tabel berikut. 
Tabel 7

Loading Factor Indikator-Indikator Variabel Penerapan Good Governance

\begin{tabular}{|c|c|c|c|c|}
\hline Construct & Indicator & Loading & Loading $^{2}$ & error variance \\
\hline \multirow[t]{5}{*}{ GG } & $\mathrm{X} .1$ & 0.853 & 0.728 & 0.272 \\
\hline & X.2 & 0.873 & 0.762 & 0.238 \\
\hline & X.3 & 0.857 & 0.734 & 0.266 \\
\hline & $X .4$ & 0.854 & 0.730 & 0.270 \\
\hline & $X .5$ & 0.623 & 0.388 & 0.612 \\
\hline \multicolumn{3}{|c|}{ Composite Reliability $=0,909$} & \multicolumn{2}{|c|}{$\mathrm{AVE}=0,668$} \\
\hline
\end{tabular}

Sumber: Hasil pengolahan data

Pada Tabel 4.1 dapat dilihat bobot faktor pada indikator X.2 (akuntabilitas) lebih besar dibanding bobot faktor 4 indikator lainnya. Artinya akuntabilitas lebih dominan dalam pembentukan variabel penerapan good governance dibanding indikator lainnya. Composite Reliability dari kelima indikator yang digunakan untuk mengukur variabel penerapan good governance sebesar 0,909 dan masih lebih besar dari yang di rekomendasikan yaitu 0,70 . Kemudian nilai average variance extracted sebesar 0,668 menunjukkan bahwa $66,8 \%$ informasi yang terkandung pada kelima indikator terwakili dalam variabel penerapan good governance.

Variabel kepercayaan konsumen diukur menggunakan lima indikator, bobot faktor (loading factor) masing-masing indikator dalam membentuk variabel kepercayaan konsumen dapat dilihat pada tabel berikut.

Tabel 8

Loading Factor Indikator-Indikator Variabel Kepercayaan Konsumen

\begin{tabular}{|c|c|c|c|c|}
\hline Construct & Indicator & Loading & Loading $^{2}$ & error variance \\
\hline \multirow[t]{5}{*}{ KK } & Z.1 & 0.479 & 0.230 & 0.770 \\
\hline & Z.2 & 0.656 & 0.430 & 0.570 \\
\hline & Z.3 & 0.496 & 0.246 & 0.754 \\
\hline & Z.4 & 0.445 & 0.198 & 0.802 \\
\hline & $Z .5$ & 0.640 & 0.410 & 0.590 \\
\hline
\end{tabular}

\begin{tabular}{cc} 
Composite Reliability $=0,679$ & AVE $=0,303$ \\
\hline Sumber: Hasil pengolahan data &
\end{tabular}

Pada tabel 8 dapat dilihat bobot faktor pada indikator Z.2 (peningkatan jumlah mustahik) lebih besar dibanding bobot faktor 4 indikator lainnya. Artinya peningkatan jumlah mustahik lebih dominan dalam pembentukan variabel kepercayaan konsumen dibanding indikator lainnya. Composite Reliability dari kelima indikator yang digunakan untuk mengukur variabel kepercayaan konsumen sebesar 0,679 dan masih lebih kecil dari yang di rekomendasikan yaitu 0,70 . Kemudian nilai average variance extracted sebesar 0,303 menunjukkan bahwa 30,3\% informasi yang terkandung pada kelima indikator terwakili dalam variabel kepercayaan konsumen.

Variabel kinerja organisasi diukur menggunakan empat indikator, bobot faktor (loading factor) masing-masing indikator dalam membentuk variabel kinerja organisasi dapat dilihat pada tabel berikut: 
Tabel 9

Loading Factor Indikator-Indikator Variabel Kinerja Organisasi

\begin{tabular}{ccccc}
\hline \hline Construct & Indicator & Loading & Loading $^{2}$ & error variance \\
\hline \multirow{6}{*}{ KO } & Y.1 & 0.875 & 0.766 & 0.234 \\
& Y.2 & 0.891 & 0.794 & 0.206 \\
& Y.3 & 0.936 & 0.876 & 0.124 \\
& Y.4 & 0.898 & 0.806 & 0.194 \\
\hline \hline
\end{tabular}

\begin{tabular}{cc} 
Composite Reliability $=0,945$ & AVE $=0,811$ \\
\hline Sumber: Hasil pengolahan data
\end{tabular}

Pada tabel 9 dapat dilihat bobot faktor pada indikator Y.3 (perpektif internal business process) lebih besar dibanding bobot faktor 3 indikator lainnya. Artinya perpektif internal business process lebih dominan dalam pembentukan variabel kinerja organisasi dibanding indikator lainnya. Composite Reliability dari kelima indikator yang digunakan untuk mengukur variabel kinerja organisasi sebesar 0,945 dan masih lebih besar dari yang di rekomendasikan yaitu 0,70 . Kemudian nilai average variance extracted sebesar 0,811 menunjukkan bahwa $81,1 \%$ informasi yang terkandung pada keempat indikator terwakili dalam variabel kinerja organisasi.

Hipotesis yang akan diuji adalah pengaruh penerapan Good Governance terhadap kinerja organisasi dan melalui kepercayaan konsumen sebagai variabel intervening. Melalui nilai-nilai yang terdapat pada diagram jalur model struktural antar variabel dapat dihitung besar pengaruh masing-masing variabel eksogen terhadap variabel endogen, yang tercermin dalam tabel berikut:

Tabel 10

Koefisien Jalur Masing-Masing Hubungan Antar Variabel

\begin{tabular}{cccc}
\hline Path & Koefisien & Std.error & T-Statistic* $^{*}$ \\
GG->KK & 0.626 & 0.0669 & 9.352 \\
GG->KO & 0.567 & 0.1337 & 4.241 \\
KK->KO & 0.190 & 0.0904 & 2.103 \\
\hline \multicolumn{4}{r}{ Sumber: Data penelitian diolah kembali *tkritis $=1,96$}
\end{tabular}

Melalui nilai-nilai yang terdapat pada diagram jalur model struktural antar variabel laten dapat dihitung besar pengaruh masing-masing variabel.

Hipotesis penelitian yang akan diuji adalah pengaruh penerapan good governance terhadap kinerja organisasi dan melalui kepercayaan konsumen terlihat dalam tabel berikut:

\section{Tabel 11}

Besar Pengaruh Langsung dan Tidak Langsung Penerapan Good Governance Terhadap Kinerja Organisasi

\begin{tabular}{|c|c|c|c|c|}
\hline Variabel & Koefisien Jalur & $\begin{array}{c}\text { Pengaruh } \\
\text { Langsung }\end{array}$ & $\begin{array}{c}\text { Melalui Kepercayaan } \\
\text { Konsumen }\end{array}$ & Total \\
\hline GG & 0,567 & $32,1 \%$ & $6,7 \%$ & $38,8 \%$ \\
\hline KK & 0,190 & $3,6 \%$ & --- & $3,6 \%$ \\
\hline
\end{tabular}

Sumber: Data penelitian diolah kembali

Selanjutnya, untuk uji signifikansi dari pengujian hipotesis penelitian akan terlihat dalam tabel berikut: 
Tabel 12

Uji Signifikansi Pengaruh Penerapan Good Governance Terhadap Kinerja organisasi

\begin{tabular}{|c|c|c|c|}
\hline Koefisien Jalur & $\mathbf{t}_{\text {-hitung }}$ & $\mathbf{t}_{\text {-kritis }}$ & Kesimpulan \\
\hline 0,567 & 4,241 & 1,96 & Terdapat pengaruh yang signifikan \\
\hline
\end{tabular}

Sumber: Data penelitian diolah kembali

Pada Tabel 12 dapat dilihat koefisien jalur penerapan good governance terhadap kinerja organisasi sebesar 0,567 dengan arah positif. Koefisien jalur yang bertanda positif menunjukkan bahwa penerapan good governance yang baik cenderung menghasilkan kinerja organisasi yang lebih tinggi. Selanjutnya nilai $t_{\text {hitung }}(4,241)$ lebih besar dari $t_{\text {kritis }}(1,96)$ menunjukkan terdapat pengaruh yang signifikan dari penerapan good governance terhadap kinerja organisasi. Secara langsung variabel penerapan good governance memberikan kontribusi atau pengaruh sebesar $32,1 \%$ terhadap kinerja organisasi, kemudian pengaruh secara tidak langsung melalui kepercayaan konsumen sebesar $6,7 \%$. Secara total penerapan good governance memberikan kontribusi atau pengaruh sebesar 38,8\% dalam meningkatkan kinerja organisasi. Hasil uji statistik sesuai dengan ekspektasi peneliti, yaitu jika penerapan good governance semakin baik maka kinerja organisasi cenderung meningkat. Hasil uji statistik telah membuktikan adanya pengaruh yang signifikan dari penerapan good governance terhadap kinerja organisasi.

\section{Simpulan}

Berdasarkan analisis data dan pembahasan hasil penelitian pada bab-bab sebelumnya, maka dapat ditarik beberapa kesimpulan, sebagai berikut: Pengaruh penerapan good governance terhadap kinerja organisasi melalui penerapan kepercayaan konsumen. Artinya penerapan good governance semakin baik, yang berdampak pada meningkatnya kepercayaan konsumen maka kinerja organisasi dengan menggunakan model balanced scorecard cenderung meningkat.

\section{Daftar Pustaka}

Aji Purba Trapsila, 2008. Implementasi Konsep Balanced Scorecard (BSC) pada Lembaga Amil Zakat. website Ekonomi Islam Online: 23

Almisar Hamid:2009. Nasib Lembaga Amil Zakat di Indonesia. Artikel ini dimuat pada Harian Republika, Jum'at 05 Juni 2009.

Ancella Anitawati Hermawan. 1996. Balanced Scorecard Sebagai Sarana Akuntansi Manajemen Strategik. IAI - Pra-Konvensi Nasional Akuntansi ke-3. Pendidikan Profesi Berkelanjutan (PPL). September 1996. Semarang.

Anthony, Robert N and Vijay Govindrajan.2003. Management Control System. Eleven Edition. Boston Mc Graw Hill Inc.

Aras Guler and David Crowther.2008. Governance and Sustainability: An Investigation Into The Relationship Between Corporate Governance and Corporate Sustainability. Emerald Journal: 444

Asep Saefuddin Jahar, Zakat Antar Bangsa Muslim: Menimbang Posisi Realistis Pemerintah dan Organisasi Masyarakat Sipil. Makalah disajikan dalam media Jurnal Zakat dan Empowerment Vol 1 Agustus 2008, diterbitkan oleh Indonesia Magnificence of Zakat (IMZ)

Bloemarat, Josee and Gaby Odekerken-Schroede. 2001. The Relationship Between Customer Loyalty and Customer Satisfaction. International Journal of Contemporary Hospitality management: 213-217. 
Buytendijk, Frank. 2009. Trust, Relationship and Performance. Journal Management Excellent:Creating Value Issue. The Article Performance Leadership: 2

Christian Herdinata. 2008. Good Corporate Governance Vs Bad Corporate Governance : Pemenuhan Kepentingan Antara Para Pemegang Saham Mayoritas dan Pemegang Saham Minoritas. Makalah ini disajikan dan diterbitkan dalam Proceeding The 2nd National Conference UKWMS Surabaya, 6 September 2008: 14-15

Circle Of Information And Development (CID) Dompet Dhuafa Republika dan Lembaga Kajian Islam Dan Hukum Islam (LKIHI) Fakultas Hukum Universitas Indonesia.2008. Naskah Akademis Rancangan Undang-Undang Republik Indonesia Tentang Pengelolaan Zakat.

Cooper, D. R, \& Schindler, P. S. (2006). Business Research Methods (9 $9^{\text {th }}$ ed.). International edition. Mc Graw Hill.

Deddy Supardi Aman Saputra. 2005. Pengaruh Peran Dewan Komisaris, Formulasi Strategi dan Penerapan Pengendalian Intern serta Pengembangan Tata Kelola Perusahaan Terhadap Kinerja Bisnis. Program Pasca Sarjana Universitas Padjadjaran. Bandung

Dikdik Tandika.2009. Analisis Faktor-Faktor Yang Mempengaruhi Kinerja Organisasi dan Implikasinya Terhadap Akuntabilitas Publik Organisasi Pengelola Zakat (OPZ) Dalam Upaya Optimalisasi Penghimpunan Zakat di Propinsi Jawa Barat, Banten dan DKI Jakarta. Program Pasca Sarjana Universitas Pasundan. Bandung

Djailani, 2003. Strategi Bazis DKI Dalam Menyiasati Implementasi UU No. 38 Tahun 1999 Tentang Pengelolaan Zakat, Forum Zakat (FOZ).

Donney Patricia M and Joseph P Canon. 1997. An Examination of The Nature of Trust in Buyer Seller Relationship. Journal of Marketing 61: 35-51

Efri S. Bahri. Mengukur Kualitas Manajemen Zakat. Artikel ini dimual dalam kumpulan artikel Community for Economic Enlightenment:

Egan, John. 2001. Relationship Marketing: Exploring Relational Strategies in Marketing. Kuala Lumpur Malaysia: Prentice Hall

Eri Sadewo. 2004. Manajemen Zakat (Tinggalkan 15 tradisi, terapkan 4 prinsip dasar). Institut Manajemen Zakat (IMZ), Media Jurnal Zakat dan Empowerment Vol 1 Agustus 2008, Indonesia Magnificence of Zakat (IMZ). Jakarta: 27

Feroz, Ehsan H, Sanjay Goel and Raymond L Raab. 2008. Performance Measurement for Accountability in Corporate Governance. Review of Accounting and Finance. Vol 7. No.2.2008: 128

Forum for Corporate Governance in Indonesian (FCGI). 2002. Tata Kelola Perusahaan (Corporate Governance) The Essence of Good Corporate Governance: Konsep dan Implementasi Perusahaan Publik dan Korporasi Indonesia. Yayasan Pendidikan Pasar Modal Indonesia \& Sinergy Communication.

Hodge B.J, William P. Anthony dan L. Gales .1996. Organizational Stratgey and Firm Performance, Southmerster. Cincinatti.

I Ketut Mardjana. I Ketut 2002. Corporate Governance dan Privatisasi. The Essence of Good Corporate Governance: Konsep dan Implementasi Perusahaan Publik dan Korporasi Indonesia. Yayasan Pendidikan Pasar Modal dan Sinergy Communication.

Imelda RHN. 2004. Implementasi Balanced Scorecard pada Organisasi Publik. Jurnal Akuntansi dan Keuangan Vol 6. No 2. Nopember 2004: Jurusan Akuntansi, Fakuitas Ekonomi Universitas Kristen Petra Surabaya: 106-122

Indra Bastian, 2006. Akuntansi Sektor Publik. Jakarta : Penerbit Erlangga. 
Jamil Azzaini.2008. Berdayakan Lembaga Amil Zakat. Artikel ini dimuat dalam Tabloid Republika. Jumat, 19 September 2008

Jan Hoesada.2002. Akuntansi Organisasi Nirlaba: Akuntansi di Indonesia di Tengah Kancah Perubahan. Makalah yang disajikan dalam seminar "Transparancy International Indonesia". Jakarta: 6

Kementrian BUMN. 2002. Keputusan Menteri Negara Badan Usaha Milik Negara Nomor:Kep-117/M-MBU/2002 Tentang Penerapan Praktek Good Corporate Governance Pada Badan Usaha Milik Negara (BUMN).

Keputusan Menteri Agama Republik Indonesia Nomor 373 tahun 2003, tentang Pelaksanaan Undang-Undang Nomor 38 Tahun 1999, tentang Pengelolaan Zakat.

Keputusan Direktur Jenderal Bimbingan Masyarakat Islam dan Urusan Haji Nomor D/291 Tahun 2000 Tentang Pedoman Teknis Pengelolaan Zakat.

Khotibul Umam, S.H. Karina Dwi Nugrahati P, dan Sekar Ayu.2009. Implementasi Prinsip Good Corporate Governance Sebagai Upaya Untuk Meningkatkan Kepercayaan pada Bank Syariah. Artikel ini dimuat dalam Economic Journal Online: 1

Kotler Philip \& Kevin Lane Keller. 2009. Marketing Management. Thirteenth Edition, New Jersey; Pearson Education Inc.

Philip. Dyson. Moore. Alsop, Godin. 2004. Managing, Customer Relationship, New Jersey; Published by John Wiley \& Sons, Inc. Hoboken.

Philip and Amstrong. 2001. Principles of Marketing, A Division of Simon \& Scuter, Engelwood Clif, New Jersey; Prentice Hall International Inc.

Mahmudi. 2007. Manajemen Kinerja Sektor Publik. Edisi Revisi. Yogyakarta: Penerbit UPP STIM YKPN

Manguns. 2010. Good Governance dan LSM. Riset pada lembaga pengawasan masyarakat atas APBD dan LSM: 17

OECD. 1999. Business Sector Advisory Group on Corporate Governance.Pepper. Don and Rogers Martha. 2004. Managing Customer Relationships. New Jersey; John Wiley \& Sons, Inc.

Rambat, Lupiyodi dan A. Hamdani. 2008. Manajemen Pemasaran Jasa. Edisi 2. Jakarta Penerbit Salemba Empat.

Sandry Satriago. 2008. Harus Mampu Mengelola Kesinambungan Daya Saing Perusahaan. (www.portalho.com:selasa 29 Januari 2008)

Sekaran Uma.2006. Research Methods For Business. Edisi 4 (Edisi bahasa Indonesia). Buku 1 dan Buku 2. Penerbit Salemba Empat. Jakarta

Sideshmukh, Deepak; Jaddig Singh; Berry Sabol. 2002. Customer Trust, Value and Loyalty in Relational Exchanges. Journal of Marketing, 66. Chicago: 15-37

Soegiharto. 2005. Peran Akuntan Dalam Menegakkan Good Corporate Governance. Auditor No 18.

Soewarso Hardjosoedarmo. 2002. Total Quality Management. Penerbit ANDI. Yogyakarta

Soni Yuwono, Edy Sukarno dan Muahmmad Ihsan.2007. Balanced Scorecard: Menuju Organisasi Berfokus pada Strategi. Jakarta: Penerbit Gramedia Pustaka Utama.

Sri Fadilah, 2011. Analisis Pengaruh Implementasi Pengendalian Intern dan Total Quality Management Terhadap Penerapan Good Governance. Hasil riset disajikan dalam Simposium Nasional Akuntansi (SNA) ke-14 di Universitas Syiah Kuala Nangroe Aceh Darussalam Juli2011, merupakan riset yang didanai LPPM Unisba. Ikatan Akuntan Indonesia (IAI), Jakarta

Sugiyono.2007. Metode Penelitian Bisnis:Pendekatan Kuantitatif, Kualitatif dan R \& D. Bandung: Penerbit Alfabeta 
Suharsimi Arikunto. 2006. Prosedur Penelitian: Suatu Pendekatan Praktik. Jakarta:Penerbit Rineka Cipta.

Susanto. A. A, 2002. "Zakat Sebagai Pengurang Penghasilan Kena Pajak: Sebuah Tinjauan Makro Ekonomi". Makalah disajikan dalam Simposium Nasional Ekonomi Islam, Yogyakarta.

Taylor, Steven A .2001. Assessing The Use of Regression Analysis in Examining Servicee recovery in The Insurance Industry: Relating Service Quality, Customer Satisfaction and Customer Trust. Journal of Insurance Issues, 24 ( 1 \& 2): 30-57.

Thurau, Hening Thorsten, Kevin P Gwinner and Dwayne D Gremble. 2002. Understanding Relationship Marketing Outcomes. Journal of Service Research. Vol 4 No. 3: 230-247.

Undang-Undang No 38 Tahun 1999 tentang Pengelolaan Pajak

Wahyudin, Zarkasyi. 2007. Peran Komite Audit dan Audit Internal Dalam Implementasi Good Corporate Governance dan Dampaknya Terhadap Kinerja Badan Usaha Milik Negara di Indonesia. Disertasi. Bandung. Program Pascasarjana Universitas Padjadjaran

Zikmund William G. et al. 2010. Business Research Methods. Eighth Edition. SouthCanada: Western Cengage Learning. 